taken by lightning and some of its effects are discussed in Chapter 3, which is followed by two chapters dealing mainly with Dr. Schonland's own experiments on the luminous processes and the electrical characteristics of lightning discharges. Chapters 6 and 7 deal respectively with the methods of protection against lightning and the mechanisms of electrification of thunderclouds. In the final chapter, radio atmospherics, and their utilization for the location of thunderstorms by direction-finding methods, are discussed.

The book is clearly intended primarily to appeal to the general reader and is most successful in this respect. From the point of view of the specialist, however, it has the defect that the treatment is descriptive only and that few references are given to the published sources of the experimental work described. Nevertheless, it will be read and enjoyed by all specialists who like to have an elementary but authoritative account of the subject.

There is as yet no comprehensive book dealing with the physies of lightning discharges to which the research worker in the field, whether physicist, meteorologist or electrical engineer, can refer. It is to be hoped that the present book will prove to be the precursor of a research monograph on lightning by Dr. Schonland in which the admirable lucidity of the present volume will be combined with a deeper treatment of the subject. J. M. Meek

\section{UNIVERSITIES OF THE BRITISH COMMONWEALTH}

The Yearbook of the Universities of the Commonwealth, 1951

(Published for the Association of Universities of the British Commonwealth.) Pp. xxxi + 1416. (London: G. Bell and Sons, Ltd., 1951.)

TT is approximately a year since the previous 1 edition of this "Yearbook" was published, and, as stated in the preface of the present volume, the aim is to issue future editions in the first quarter of each year. The book is published by the Association of Universities of the British Commonwealth and records details for all university institutions of the Commonwealth and not merely member institutions of the Association.

Besides the usual information on the lines of former issues, there are reports of events of outstanding interest which have occurred since the compilation of the previous edition. Thus the present publication records the inauguration of the University College of North Staffordshire and of the New South Wales University of Technology; Memorial University College, St. John's, has become the Memorial University of Newfoundland, and the University College of the Orange Free State has also been elevated to university status. For the first time, entries have been made for the Canadian institutions of Mount St. Vincent College, St. Dunstan's College, St. Joseph's College and Sir George Williams College; for the Indian Universities of Jammu and Kashmir, and Poona; and a full entry for the University of Malaya. As a result of the separation of the Republic of Ireland from the Commonwealth in 1949, the entries for the Universities of Eire have been placed in an appendix. A further alteration has resulted by the advent of the new General Certificate of Education, and Appendix 1, which deals with the matricu- lation requirements for United Kingdom universities, has been accordingly amended.

Of the main contents of the book, suffice it to say that there are the usual compilations relating to staff (approximately 28,000 names); general information; new events; introductory chapters on the history, regulations and practices of the universities in the different countries; and appendixes, dealing with a variety of subjects such as postgraduate awards tenable in the United Kingdom (which is also available as a separate pamphlet) and overseas, statistics on overseas students in the United Kingdom, the Inter-University Council for Higher Education in the Colonies, and information for those intending to study in the United States. An index of names and a general index round off the work.

Little further need be added about this excellent publication, except perhaps the rather obvious remark that for a volume of its size it contains an extraordinarily large amount of useful information.

\section{EARTH WAVES}

\section{Earth Waves}

By Prof. L. Don Leet. (Harvard Monographs in Applied Science, No. 2.) Pp. v+122. (Cambridge, Mass. : Harvard University Press; New York: John Wiley and Sons, Inc.; London: Chapman and Hall, Ltd., 1950.) 24s, net.

UCE of the material of this instructive little 1 book was collected by Prof. L. Don Leet for presentation as a course of eight lectures on the "Applications of Seismological Techniques to Engineering Problems" for the Lowell Institute of Boston. He has had wide experience in the use of the seismic method in prospecting for oil and bauxite, and has made a special study of the earth motion resulting from the atomic bomb test in New Mexico in 1945. Prof. Leet, who is professor of geology in Harvard University and seismologist in charge of Harvard Seismograph Station, has developed a three-component portable seismograph.

This book is a model of clarity, and, although first-year university standard in mathematics and physics is assumed, the reader need not have any prior knowledge of either geology or seismology. The book is well illustrated with line diagrams of apparatus, graphs, terrestrial sections and seismograms. It is divided into four chapters. The first deals largely with forced vibrations and the theory of the seismograph. The second chapter discusses the major types of waves observed in seismology, and it is to be noted that the symbols used for elastic constants are in accordance with the American Standards Publication ASAZ 10.6-1948 (American Society of Mechanical Engineers, New York, 1948). Some of these symbols differ from those in current use in the literature of seismology, though there need be no confusion since Prof. Leet is careful to list and explain all symbols used. Chapter 3 deals with the effect on earth waves of various earth structures commonly met with, and the consequent variation in seismograms. The final chapter treats of microseisms and the use of the tripartite seismograph installation to track storms at sea.

The whole work is a most valuable bridge between theoretical and practical seismology. Full references are given, there is an adequate index, and the printing and format leave little to be desired.

ERnest TILLOTSON 